\title{
Correction to: Contextual Application of Pulse-Compression and Multi-frequency Distance-Gain Size Analysis in Ultrasonic Inspection of Forging
}

\author{
M. K. Rizwan ${ }^{1}$ - L. Senni ${ }^{2}$ P. Burrascano ${ }^{1}$ - S. Laureti ${ }^{1}$ - M. Goldammer ${ }^{3} \cdot$ H. Mooshofer ${ }^{3} \cdot$ R. Borgna ${ }^{4} \cdot$ S. Neri ${ }^{4}$. \\ M. $\operatorname{Ricci}^{5}$
}

Accepted: 27 January 2021 / Published online: 2 March 2021

(C) The Author(s) 2021

\section{Correction to: J Nondestruct Eval https://doi.org/10.1007/s10921-019-0612-7}

The article "Contextual Application of Pulse-Compression and Multi-frequency Distance-Gain Size Analysis in Ultrasonic Inspection of Forging", written by M. K. Rizwan . L. Senni · P. Burrascano - S. Laureti · M. Goldammer · H. Mooshofer $\cdot$ R. Borgna $\cdot$ S. Neri $\cdot$ M. Ricci, was originally published electronically on the publisher's internet portal on 26 July 2019 without open access. With the author(s)' decision to opt for Open Choice the copyright of the article changed on 2 January 2021 to () The Author(s) 2021 and the article is forthwith distributed under a Creative Commons Attribution 4.0 International License, which permits use, sharing, adaptation, distribution and reproduction in any medium or format, as long as you give appropriate credit to the original author(s) and the source, provide a link to the Creative Commons licence, and indicate if changes were made. The images or other third party material in this article are included in the article's Creative Commons licence, unless indicated otherwise in a credit line to the material. If material

The original article can be found online at https://doi.org/10.1007/ s10921-019-0612-7.

M. Ricci

marco.ricci@unical.it

1 Dipartimento di Ingegneria, Università di Perugia, Perugia, Italy

2 Istituto per le Applicazioni del Calcolo, Consiglio Nazionale delle Ricerche, Rome, Italy

3 SIEMENS AG Corporate Technology, Munich, Germany

4 Acciai Speciali Terni, Terni, Italy

5 Dipartimento di Ingegneria Informatica, Modellistica, Elettronica e Sistemistica, Università della Calabria, Rende, CS, Italy is not included in the article's Creative Commons licence and your intended use is not permitted by statutory regulation or exceeds the permitted use, you will need to obtain permission directly from the copyright holder. To view a copy of this licence, visit http://creativecommons.org/licenses/by/4. 0 .

Open Access This article is distributed under the terms of the Creative
Commons Attribution 4.0 International License (http://creativecomm
ons.org/licenses/by/4.0/), which permits unrestricted use, distribution,
and reproduction in any medium, provided you give appropriate credit
to the original author(s) and the source, provide a link to the Creative
Commons license, and indicate if changes were made.

Publisher's Note Springer Nature remains neutral with regard to jurisdictional claims in published maps and institutional affiliations. 